\title{
Importance Performance Analysis using Dematel: A Case Study on Tourist Destination Attributes in Manado Indonesia
}

\author{
Magdalena Wullur* and Valen Samehe \\ Study Program of Management, Faculty of Economics and Business, University of Sam Ratulangi, \\ Kampus UNSRAT Bahu, Manado 95115, Indonesia
}

\begin{abstract}
The article discusses the important and influential tourist destination attributes for foreign tourists. The study was conducted on 40 respondents who were considered experts in providing an assessment of tourist destinations in the city of Manado, Indonesia. This study uses the combination of the Importance Performance Analysis (IPA) approach and decision making and evaluation laboratory (DEMATEL) technique. The main results indicate that the attributes of cleanliness, neatness, greening, and fresh air are very important and have a significant influence on other attributes but are not satisfactory. This attribute is a critical priority that must be improved by decision makers, so that the tourist destination development program in the city of Manado becomes efficient and effective. Meanwhile, friendly community and delicious cuisine are very important attributes and have significant influence on other attributes, the performance is very satisfying for tourists, and this attribute needs to be maintained.
\end{abstract}

Keywords: Decision making, improving the performance of tourist destinations, increase tourist, tourism business, studies attributes

\section{Introduction}

Knowing the attributes for tourist destination that can satisfy tourists is very important for decision makers in the tourism business $[1,2]$. Tourist satisfaction indicates that tourist destinations can meet their needs and desires. Tourists who are satisfied with a tourist destination may be due to their attractiveness (tourist objects and attractions), affordable prices, cleanliness and beauty, as well as other attributes such as accommodation, transportation, cafes and bars, sports activities, travel agents, information services [3, 4]. Furthermore, every tourist has certain expectations when choosing a tourist destination to visit. At the time of the visit, they expected these attributes to be available. Their expectations can include various attributes such as the attractiveness of destinations, products and tourist attractions they have, facilities (entertainment, culinary, accommodation, transportation) and prices [5]. This expectation can grow high or even decrease depending on the publicity and information obtained by tourists. The higher the expectations of a destination, the higher the demands for meeting those expectations.

\footnotetext{
* Corresponding author: wullurmagdalena@yahoo.com
} 
Expectations will affect satisfaction and the logical consequences will affect the decision to make a revisit and can even influence the decisions of other tourists [6].

This article discusses a case study of tourist destinations in the city of Manado, Indonesia. In the last $3 \mathrm{yr}$, the level of tourist visits to the city of Manado is very high, increasing three times. In 2018, the number of tourist visits increased significantly after opening of direct flights from China. To serve tourists, the Manado city government prepares various tourist destination areas by providing various attractions and tourist facilities, so the tourists stay longer and shop more. By providing various tourist facilities, the government incurs a lot of costs. In order to be effective in developing the city's tourist areas, there needs to be empirical data documenting the level of tourist expectations and satisfaction. This data is needed to be the basis for decision making in determining tourism policies, developing tourism products and attractions, developing new destinations and new attractions as well as other relevant policies that will ensure the continuity of visits in the future.

The largest number of foreign tourists to the city of Manado comes from China. According to Choibamroong [7], Chinese tourists are classified into two groups namely the general Chinese tourists (earning $\leq \mathrm{CNY} 10000 \mathrm{mo}^{-1}$ ) and the quality Chinese tourists (earning CNY 10000 or more $\mathrm{mo}^{-1}$ ). The two groups have different views and characters about the attributes that are important, the general one group are those who are mostly involved with travel in tourism activities and in terms of visiting or engaging in tourist attractions, this group does not experience difficulties. Whereas the quality ones are those who mostly plan their own trips, in this case they experience some difficulties when arriving at a tourist destination because information services are not available, such as Chinese and English. So the quality one group is those who expect something special or in accordance with their expectations from a destination because tourism activities must provide benefits to the body and mind [8].

The importance of each attribute of a tourist destination can be measured by the Importance Performance Analysis (IPA), by measuring the importance of each attribute, then looking for the gap with the satisfaction of each attribute felt or experienced by each tourist [9-11]. However, measurement by IPA has a weakness, namely IPA views each attribute as independent. In reality, there is a dependency or cause-and-effect relationship among an attribute and others, so that if an attribute is the cause of many attributes, the level of importance of the attribute will be greater, then the performance of the attribute needs to get more priority [12]. Likewise, if an attribute is the result of most of the other attributes, then that attribute can be of more concern for knowing the performance of most other attributes. The importance of tourist destination attributes can be analyzed more deeply through cause and effect relationship. Attributes that have an impact on other attributes, or conversely those affected by the others, are very important or have a high prominence. In this report, a method using the decision making trial and evaluation laboratory (DEMATEL) for analysis of cause and effect relationships among tourism attributes as a method to calculate will be presented [13].

\section{Literature review}

A tourist attraction is anything that is interesting and is worth visiting and seeing [14]. The attractiveness of a tourist destination is supported by tourist objects and attractions that can amaze and satisfy the visitors. Tourist attraction is the main focus of tourism drivers in a destination, which motivates tourists to visit a place, something that has a uniqueness, convenience, and value in the form of diversity of natural wealth, culture, and man-made products that are targeted or tourist visit. A tourist attraction must meet the requirements for the development of the region, the requirements are (i) what to see, i.e. in that place must 
have special attractions and cultural attractions that can be used as "entertainment" for tourists. What to see includes natural scenery, activities, arts and tourist attractions. (ii) What to do, i.e. a recreational facility that can make tourists feel at home in that place. (iii) What to buy, i.e. tourist destinations must be available facilities for shopping, especially souvenirs and folk handicrafts as souvenirs for return to the place of origin. (iv) What to arrive, which includes accessibility to visit the tourist attraction such as what vehicle is used and how long it will take to arrive at the destination. (v) What to stay, i.e. how a tourist will stay for a while during his vacation such as lodging (starred and nonstarred hotels).

One important thing to develop tourism is through easy access and use of facilities [15]. It is not uncommon for tourists to visit a place or region or country, because they are attracted by the facilities that can be obtained through the facilities. According to Yoeti [16] tourist facilities are all facilities whose function is to meet the needs of tourists who live for a while in the tourist destination they visit, where they can relax and enjoy and participate in activities available in the tourist destination. The components of tourism facilities include accommodation units, namely hotels, motels, apartments, villas, campsite, caravan, parks, hostels and condominiums. Restaurants, bars and cafes, which range from fast food through to luxury restaurants. Transports at the destination, namely taxis, coaches, car rentals, and cycle hire destinations. Sport and activities, namely ski school, sailing school, golf clubs. Other facilities, namely craft courses, language schools. Retail outlets, namely shops, travel agents, souvenir shops, camping supplies. Other services, namely hairdressing, information services, and tourist polices.

Based on previous studies that discuss tourist destinations expected by tourists find some interesting attributes. Tourist destinations need to provide food and beverage restaurants, historical sites, good cultural values, nature and accommodation and hospitality of residents [1]. Infrastructure plays an important role in exploring tourist areas, tourists' expectations and satisfaction mainly in infrastructure [17]. Tourist satisfaction depends on the quality of vacation service packages [9]. Tourists have very high expectations of the attractiveness of destinations, especially in the ease of transportation, communication, attractions and tourism activities [6]. The tourist destinations of Langkawi in Malaysia offer beautiful natural scenery, reliable transportation, accommodation, and the availability of adequate tourist facilities [3]. Learning from the experience of tourists as pedestrians in the historic area in Kuala Lumpur, Malaysia, shows that various activities along the route are a memorable experience [4]. Attributes that have a high level of importance with low performance for tourism in the city of Semarang, Indonesia include performances of traditional arts and maintenance and management of indigenous cultural tourism [18]. Tourists are very satisfied with the availability of facilities such as drinking water, transportation, and medical facilities [19]. Tourists from China who have high incomes choose to arrange their own travel and stay in five-star hotels, so these tourists have their own expectations [7]. Physically the quality and quantity of public facilities, public infrastructure and tourism facilities in the Malioboro region, Indonesia has increased but has not yet met the level of tourist expectations. They are dissatisfied with the facility because tourist expectations are greater than performance [20].

Furthermore, the price attribute is also another attribute that tourists consider. According to Lupiyoadi [21], prices are the various benefits possessed by a service product compared to the various costs (sacrifices) incurred in consuming these services. These costs can be in the form of time that must be sacrificed to get services, physical effort (energy expended to get services), mental burden (stress), and sacrifices related to the senses (noise, heat, etc.). Price is something that is determined as a reward for traded services or goods. According to Kotler and Keller [22], price is the value of money to generate income and expenses. According to Kotler et al. [23], prices are simply translated as a fixed amount of 
money for goods and services. Price is a number of exchanges of consumer value in order to benefit when using a product or service. Prices have many names, namely the rates when tourists stay at lodging/star and non-star hotels, the cost of plane tickets, trains, taxis and buses, bank interest or exchange rates, shopping fees, or entrance fees at each tourist location.

\section{Research design}

This research is based on theoretical and empirical studies in determining the importance attributes for tourist destinations. To explore the attributes empirically, three types of closed questionnaires were developed to ask to the respondent, i.e. (i) the expectations of foreign tourists visiting Manado, (ii) their satisfaction after gaining experience there, and (iii) the direct influence relationship between attributes. There are 40 respondents (tourists) who are willing to complete the questionnaire. The mapping of the expectations and satisfactions of each attribute on Cartesian diagram was done by averaging respond of all tourist. This mapping is called the Importance Performance Analysis (IPA) with the position of each attribute is divided into four quadrants, as follows Johann [9] and Bagri and Kala [24]: The first quadrant (keep up the good work) is an area that contains attributes that are considered important and are considered in align with what they feel so that the level of satisfaction is relatively higher. The attributes included in this quadrant must be retained. The $2^{\text {nd }}$ quadrant (concentration area) is an area that contains attributes that are considered important, but in fact these attributes are not in line with the expectations (the level of satisfaction obtained is still low). The attributes included in this quadrant must be increased. The $3^{\text {rd }}$ quadrant (low priority area) is an area that contains attributes that are considered less important and in fact the performance is not too special. The increasing in this attributes shall be reconsidered. The $4^{\text {th }}$ quadrant (possible over skill area) is an area that contains attributes that are considered less important and is felt to be very excessive $[10,11,18]$.

IPA only gives partial information for each of attribute's importance level. All attributes are considered independent each other. In reality, some attributes have causal relation among them [12]. To handle this condition, was developed the decision making trial and evaluation laboratory (DEMATEL) method to calculate the direct influence relationship between attributes, indirect relationships, and the level of dominance of each attribute [13]. The purpose of this method was to visualize and analyze the structure of cause and effect relationships among several attributes in a system. The method can be implemented to find interdependence among attributes and further develop an impact-relation map that shows relative relationships within the attributes. The method can be used for studying and solving complex and intertwined problems. Furthermore, it finds the prominent attributes of a complex structure system based on the impact-relation diagram [25].

There are four stages to implement the DEMATEL method [12, 13, 25]:

First stage is construct the direct-relation matrix from $n$ attributes $\left\{A_{1}, A_{2}, \ldots, A_{n}\right\}$ in a system and $m$ experts or respondents $\left\{E_{1}, E_{2}, \ldots, E_{m}\right\}$ in the decision group who are asked to determine the direct influence of attribute $A_{i}$ towards attribute $A_{j}$ using Likert scale. In this research, using five points scale, score 0 for "no influence", score 1 for "low influence", score 2 for "medium influence", score 3 for "high influence", and finally score 4 for "very high influence" $[6,8]$. Then the individual of the direct-relation matrix is formed for each expert,

$$
Z_{k}=\left[z_{i j}^{k}\right]_{n \times n}
$$

It represents $k^{\text {th }}$ expert's judgment regarding the level of influence attribute $A_{i}$ towards attribute $A_{j}$. By combining $m$ experts' decisions, the group of the direct-relation matrix can be obtained by 


$$
z_{i j}=\frac{1}{m} \sum_{k=1}^{m} z_{i j}^{k} \text { where } i, j=1,2, \ldots, n .
$$

The $2^{\text {nd }}$ stage, i.e. normalize the direct-relation matrix to obtain $N$, i.e. normalized group of the direct-relation matrix $N=Z / M$ where

$$
M=\max \left(\max _{1 \leq i \leq n} \sum_{j=1}^{n} z_{i j}, \max _{1 \leq j \leq n} \sum_{i=1}^{n} z_{i j}\right)
$$

The $3^{\text {rd }}$ generate the total-relation-matrix $T=\left[t_{i j}\right]_{n \times n}$ using the normalized the directrelation matrix by aggregating the direct and indirect effects as follows

$$
T=N+N^{2}+N^{3}+\cdots+N^{w}=N(I-N)^{-1} \text { when } w \rightarrow \infty
$$

Finally the $4^{\text {th }}$ stage, develop the influential-relation map from vectors $R$ and $C$, vectors that consist of sum of rows and columns of matrix $T$, respectively, i.e.

$$
R=\left[r_{i}\right]_{n \times 1}=\left[\sum_{j=1}^{n} t_{i j}\right]_{n \times 1} \text { and } C=\left[c_{j}\right]_{1 \times m}=\left[\sum_{i=1}^{n} t_{i j}\right]_{1 \times n}
$$

Hence, $R$ is the total effect, which is the sum of the direct and indirect effects, conveyed by attribute $A_{i}$ to other attributes. Similarly, $C$ is the total effect that attribute $A_{j}$ received from other attributes. When $i=j$ and $i, j \in\{1,2, \ldots, n\}$, the vector $(R+C)$ demonstrates the degree of importance of an attribute in the system. It shows the intensity of the effect dispatched and received by that attribute. This is called "prominence", which plays an important role in the decision making process. The relative effect of an attribute shown by $(R-C)$ is called "relation", and this is the net effect of an attribute contributed to the system. Positive net effect $\left(r_{i}-C_{i}\right)$ represents an active influence given by attribute $A_{i}$ to others, while negative net effect shows that $A_{i}$ is receiving influence from other attribute. Attributes with positive relation is gathered into cause group, while the other into effect group. Furthermore the dataset $(R+C, R-C)$ is mapped to produce the influential-relation map [12, 13, 25]. Both of these methods serve as guidelines in determining the priority of developing tourist destination attributes, specifically the tourist destinations of Manado City, Indonesia.

\section{Disscussion and analysis}

\subsection{Tourist destination attributes}

Based on theoretical and empirical studies in the previous section, it was found that the attributes of tourist destinations can be grouped into three indicators, namely (i) tourist attraction [1-3, 10, 24], (ii) tourist facilities [1-4, 6, 8, 9, 17, 20, 24], and (iii) prices [21-23]. Attributes of tourist attractions, namely cleanliness and tidiness (hereinafter abbreviated A1), greening and clean air (A2), walkable city (A3), varied tourist attractions (A4), natural attractions (mountains, islands, beaches) interesting (A5), interesting artificial attractions (sculpture, temple, bridge, natural house) (A6), friendly community (A7), least culinary (A8), availability of arts and culture (A9), and marine park which is interesting (A10). Attributes of tourist facilities, namely clean hotels and accommodation (A11), transport that reaches all tourist attractions (A12), boat, motorbike and similar vehicle rental services (A13), restaurants and cafes that provide all the needs of tourists (A14), center easily accessible tourism information (A15), explanation boards for each informative and educational attraction (A16), and convenient pedestrian (A17). Price attributes, namely the cost of entry to each cheap attraction (A18), cheap hotels and accommodation (A19), the cost of renting boats, motorbikes and cheap cars (A20), shopping at malls in the city of Manado is very expensive (A21), and shopping at street vendors and small kiosks is very cheap (A22). 


\subsection{Importance-Performance analysis of tourist destination expectation and satisfaction}

Based on the perception of 40 foreign tourists related to the level of importance and satisfaction (performance) of tourist destinations, it can be mapped in four quadrants of Cartesian coordinates, where the Cartesian coordinate lines are determined from the average score of all attributes of the importance level and all levels of satisfaction of all respondents (Figure 1).

The attributes that are in the first quadrant are natural attractions (mountains, islands, beaches) interesting (A5), friendly community (A7), least culinary (A8), marine park which is interesting (A10), clean hotels and accommodation (A11), and luxurious and magnificent shopping mall (A21). All of these attributes must be preserved and if necessary improved. The attributes that belong to the second quadrant are cleanliness and neatness (A1) and greening and clean air (A2). These attributes must be the main concentration to improve performance satisfaction. According to tourists, all of these attributes are very important and greatly affect their satisfaction but in the real conditions are very disappointing. The attributes that are mapped in the third quadrant are walkable city (A3), varied tourist attractions (A4), interesting artificial tourist attractions (A6), availability of arts and cultural performances (A9), tourism information center easily accessible (A15), explanation boards are very informative (A16), comfortable pedestrian (A17), cheap hotel and accommodation (A19), and cheap boat and car rental fees (A20). These attributes do not need to be prioritized for improvement because they are not so important at the moment. Finally, the attributes included in the fourth quadrant are transportation reaches all tourist attractions (A12), rent all transportation modes easily and cheaply (A13), restaurants and cafes provide all the needs (A14), entrance fees to each attraction are cheap (A18), and street vendors or small kiosks are very cheap (A22). This attribute is considered less important and is felt to be very excessive.

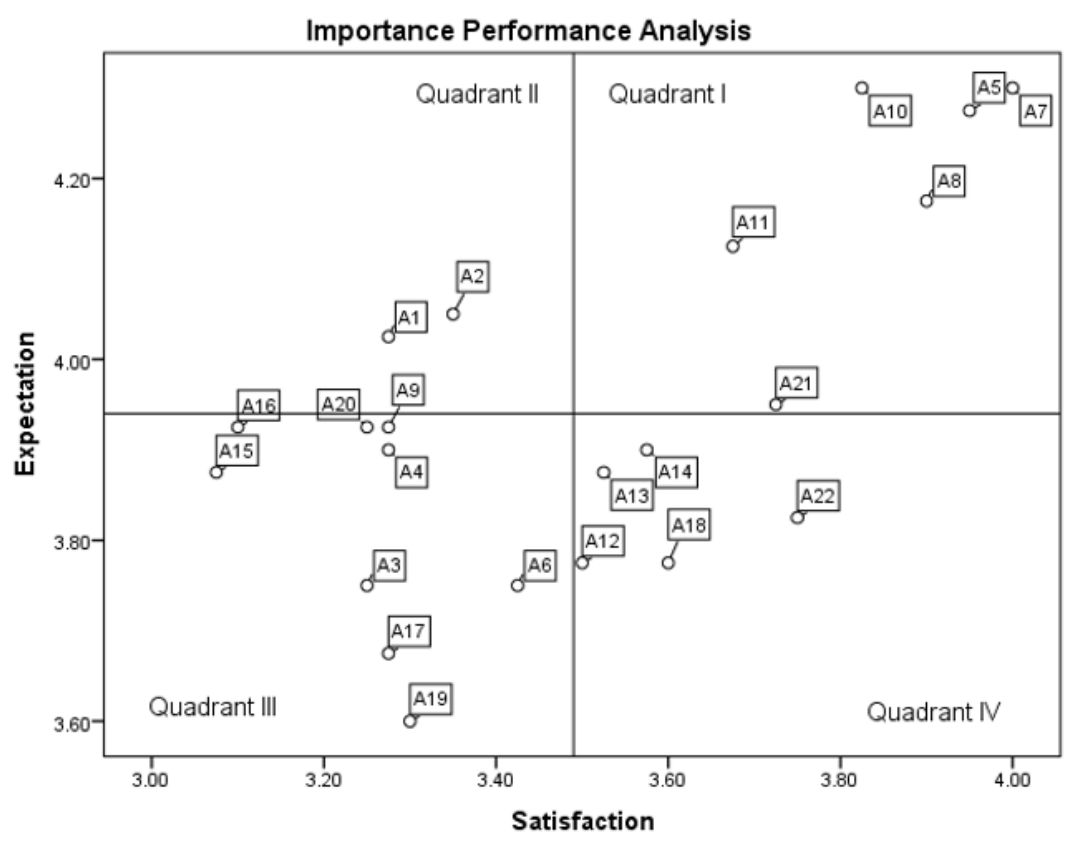

Fig.1. Importance performance analysis of tourism destination attributes 


\subsection{Prominence-relation for each Tourism Destination Attribute}

All effect pair for each tourism destination attribute (Table 1) are mapped as a prominence, $(R+C)$ on horizontal axis, and as a causal-effect relation, $(R-C)$ on vertical axis. The diagram is divided into four quadrants (Figure 2) based on average 3.40 of $(R+C)$ as the vertical divisor, and on average 0.00 of $(R-C)$ as the horizontal divisor. Each pair of attributes will fall into one of the quadrant and the overall plot provides a visualization of causal relationship among attributes and assists the tourism business decision makers in identifying the important attributes for further actions.

Table 1 show the causal-effect and prominence relation scores. It shows that cleanliness and neatness (A1), greening and clean air (A2), walkable city (A3), delicious cuisine (A8), friendly community (A7), comfortable pedestrian A (17), cheap boat and car rental fees $\mathrm{A}(20)$, transportation reaches all tourist attractions (A12), and interesting tourist icon (A10) are in causal group since $R-C>0$. They impact other attributes and therefore should be given considerable attention. The highest impacts are cleanliness and neatness (A1), greening and clean air (A2), walkable city (A3), and delicious cuisine (A8). On the other hand, interesting natural tourist attractions $\mathrm{A}(5)$, interesting artificial tourist attractions $\mathrm{A}(6)$, restaurants and cafes provide all the needs $\mathrm{A}(14)$, entrance fees to each attraction are cheap $A(18)$, varied tourist attractions $A(4)$, explanation boards are very informative $A(16)$, cheap hotel and accommodation $\mathrm{A}(19)$, street vendors or small kiosks are very cheap $\mathrm{A}(22)$, hotel and accommodation are clean $\mathrm{A}(11)$, tourism information center easily accessible $\mathrm{A}(15)$, luxurious and magnificent shopping mall $\mathrm{A}(21)$, and rent all transportation modes easily and cheaply $\mathrm{A}(13)$ are in effect group with $R-C<0$. These attributes are influenced by others, and could indirectly improve the system when their causal attributes are improved.

Furthermore, based on the prominence relation, can be seen that very interesting tourist icon $\mathrm{A}(10)$, interesting artificial tourist attractions $\mathrm{A}(6)$, varied tourist attractions $\mathrm{A}(4)$, interesting natural tourist attractions $\mathrm{A}(5)$, friendly community $\mathrm{A}(7)$, comfortable pedestrian $A(17)$, transportation reaches all tourist attractions $A(12)$, street vendors or small kiosks are very cheap $\mathrm{A}(22)$, tourism information center easily accessible $\mathrm{A}(15)$, and availability of arts and cultural performances $\mathrm{A}(9)$ are dominant attributes as they significantly affect and affected by others. Table 1 also shows that friendly community $\mathrm{A}(7)$, comfortable pedestrian $\mathrm{A}(17)$, and transportation reaches all tourist attractions $\mathrm{A}(12)$ are in the first quadrant which means they are core attributes or intertwined givers. Friendly community $\mathrm{A}(7)$ is the most important as it influence others and highly related to other attributes, and therefore should be given the utmost attention by decision maker. Greening and clean air $\mathrm{A}(2)$, cleanliness and neatness (A1), delicious cuisine (A8), walkable city (A3), and cheap boat and car rental fees $\mathrm{A}(20)$ are located in the second quadrant i.e. driving attributes as they have low prominence by high relation. Luxurious and magnificent shopping mall $\mathrm{A}(21)$, restaurants and cafes provide all the needs $\mathrm{A}(14)$, explanation boards are very informative $\mathrm{A}(16)$, cheap hotel and accommodation $\mathrm{A}(19)$, hotel and accommodation are clean $\mathrm{A}(11)$, rent all transportation modes easily and cheaply $\mathrm{A}(13)$, and entrance fees to each attraction are cheap A(18) are in third quadrant, which shows that they are relatively detached from the system with low prominence and low relation with other attributes. Interesting artificial tourist attractions $A(6)$, varied tourist attractions $A(4)$, interesting natural tourist attractions $\mathrm{A}(5)$, street vendors or small kiosks are very cheap $\mathrm{A}(22)$, and tourism information center easily accessible A(15) are placed in fourth quadrant which are called impact attributes or intertwined receivers. They have high prominence but easily influenced by other attributes. Therefore, these attributes should not be treated individually but rather in conjunction with the affecting attributes. 
Table 1. Prominence-Relation for Each Tourism Destination Attribute

\begin{tabular}{|c|c|c|c|c|c|}
\hline Indicators & Tourism Destination Attributes & $\mathrm{Ri}$ & $\mathrm{Cj}$ & $\mathrm{Ri}+\mathrm{Cj}$ & $\mathrm{Ri}-\mathrm{Cj}$ \\
\hline \multirow{10}{*}{ 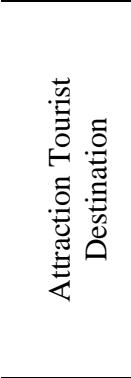 } & A1 Cleanliness and neatness & 2.07 & 0.66 & 2.73 & 1.41 \\
\hline & A2 Greening and clean air & 1.96 & 0.59 & 2.56 & 1.37 \\
\hline & A3 Walkable city & 2.01 & 1.29 & 3.30 & 0.73 \\
\hline & A4 Varied tourist attractions & 1.75 & 2.40 & 4.15 & -0.64 \\
\hline & A5 Interesting natural tourist attractions & 1.59 & 2.59 & 4.17 & -1.00 \\
\hline & A6 Interesting artificial tourist attractions & 1.70 & 2.63 & 4.33 & -0.94 \\
\hline & A7 Friendly community & 2.19 & 1.73 & 3.92 & 0.45 \\
\hline & A8 Delicious cuisine & 1.56 & 0.87 & 2.43 & 0.69 \\
\hline & A9 Availability of arts and cultural performances & 1.81 & 1.80 & 3.61 & 0.00 \\
\hline & A10 Very interesting tourist icon & 2.30 & 2.30 & 4.60 & 0.01 \\
\hline \multirow{7}{*}{ 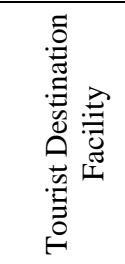 } & A11 Hotel and accommodation are clean & 1.30 & 1.55 & 2.86 & -0.25 \\
\hline & A12 Transportation reaches all tourist attractions & 1.94 & 1.77 & 3.71 & 0.17 \\
\hline & A13 Rent all transportation modes easily and cheaply & 1.43 & 1.51 & 2.94 & -0.09 \\
\hline & A14 Restaurants and cafes provide all the needs & 1.06 & 1.80 & 2.87 & -0.74 \\
\hline & A15 Tourism information center easily accessible & 1.78 & 1.91 & 3.70 & -0.13 \\
\hline & A16 Explanation boards are very informative & 1.25 & 1.72 & 2.97 & -0.47 \\
\hline & A17 Comfortable pedestrian & 2.15 & 1.70 & 3.85 & 0.44 \\
\hline \multirow{5}{*}{$\stackrel{\mathscr{E}}{\Xi}$} & A18 Entrance fees to each attraction are cheap & 1.37 & 1.97 & 3.33 & -0.60 \\
\hline & A19 Cheap hotel and accommodation & 1.38 & 1.69 & 3.07 & -0.32 \\
\hline & A20 Cheap boat and car rental fees & 1.68 & 1.36 & 3.04 & 0.32 \\
\hline & A21 Luxurious and magnificent shopping mall & 0.99 & 1.12 & 2.11 & -0.13 \\
\hline & A22 Street vendors or small kiosks are very cheap & 1.74 & 2.01 & 3.74 & -0.27 \\
\hline
\end{tabular}

Based on the IPA and Damatel analysis, friendly community (A7) and delicious cuisine (A8) are very important attributes and have a significant influence on other attributes, the performances were very satisfying to tourists, these attributes need to be maintained. However, the attributes cleanliness and neatness (A1) and greening and clean air (A2) are very important and have a significant influence on the other attributes, but are unsatisfactory. This attribute is a main priority to be addressed by decision maker.

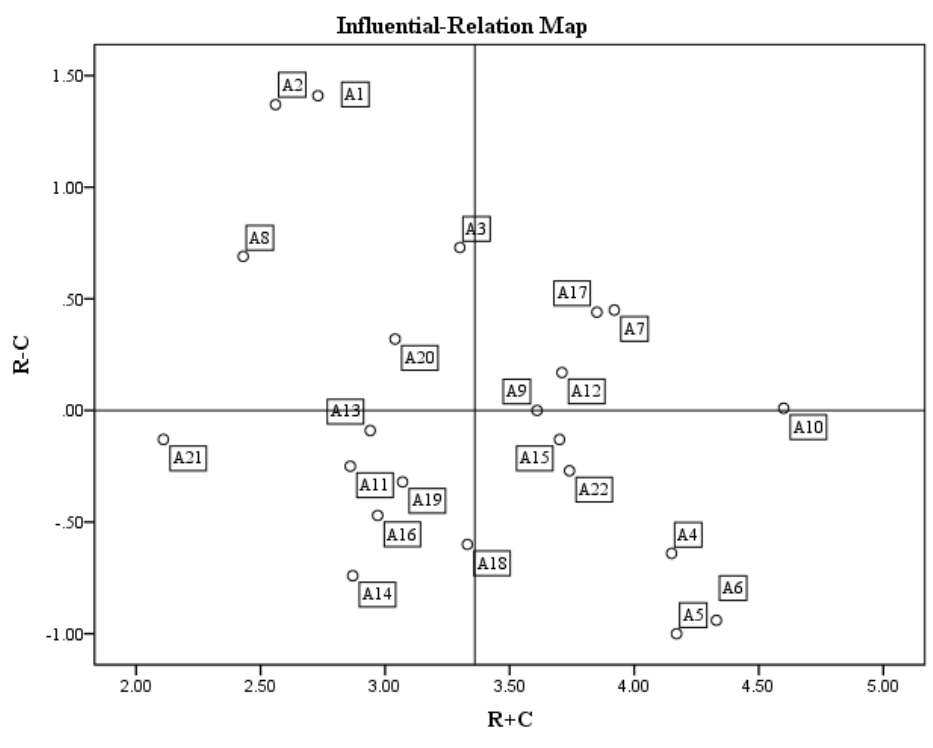

Fig. 2. Influential-relation map of tourism destination attributes 


\section{Conclusion}

This article studies attributes that importance and affecting the tourism destination decision. There are 22 attributes derived from the literature, and categorized into three groups i.e. attraction, facility, and price related to the tourism destination attributes. The analysis is done by Importance Performance Analysis and applying DEMATEL approach. The main result of this research is to find which attributes are considered very important, have a significant influence on other attributes, but the performance is very unsatisfactory, should be made as the main priority to be improved. The selection on improving the performance of this attribute is the most effective in improving the performance of tourist destinations.

There are limitations to this study, first the respondents who were experts in evaluating the attributes of the tourist destination were selected by convenience and the number was limited. The quality and quantity of data obtained does not fully represent all the tourists who visit. In the future it is necessary to determine the criteria and the appropriate number of respondents. Second, the assessment of attributes is still deterministic even though in reality they are quite vague. Therefore, future research can be extended to use fuzzy IPA and DEMATEL to accommodate this vagueness.

\section{References}

1. A.A. Aksu, E.T. İçigen, R. Ehtiyar, TURIZAM, 14,2:66-77(2010). http://scindeks.ceon.rs/article.aspx?artid=1450-66611002066A

2. Zivkovic, R.I. Brdar, The Review of International Affairs, LXVI,1157:125137(2015). http://www.diplomacy.bg.ac.rs/pdf/ria/2015/RIA1157 2015.pdf\#page $=126$

3. N. Aliman, S. Hashim, S. Wahid, S. Hardin, International Journal of Marketing Studies, 8,3:173-188(2016). https://ideas.repec.org/a/ibn/ijmsjn/v8y2016i3p173$\underline{188 . h t m l}$

4. M. Mansouri, N. Ujang, Asian Geographer, 33:1-21(2016). https://www.tandfonline.com/doi/abs/10.1080/10225706.2016.1185639

5. C.R. Goeldner, J.R.B. Ritchie, Tourism: Principles, practices and philosophies. New York: John Wiley \& Sons (2009). https://www.wiley.com/enus/Tourism\%3A+Principles $\% 2 \mathrm{C}+$ Practices $\% 2 \mathrm{C}+$ Philosophies $\% 2 \mathrm{C}+12 \mathrm{th}+$ Edition-p$\underline{9781118071779}$

6. T. Gok, K. Sayin, International Journal of Social, Behavioral, Educational, Economic and Management Engineering, 9,8:2518-2523(2015). .

https://waset.org/Publication/south-korean-tourists-expectation-satisfaction-andloyalty-relationship/10002275

7. T. Choibamroong, Asia-Pacific Social Science Review, 16,3:3045(2017). http://apssr.com/wp-content/uploads/2018/04/3-RA_Choibamroong-032017.pdf

8. J-H. Kim, Tourism Management, 44,34-45(2014). https://www.sciencedirect.com/science/article/pii/S0261517714000399

9. M. Johann, International Journal of Economic Practices and Theories, 4,5:572578(2014). $\quad$ http://www.ijept.org/index.php/ijept/article/view/The_ImportancePerformance_Analysis_an_Evaluation_of_Tourist_Satisfaction_with the Destination Attributes

10. S. Saib, M.M. Dawood, F.H. Saikim, Transaction on Science and Technology, 3,12,93-100(2016). http://tost.unise.org/pdfs/vol3/no1_2/31-2_93 100.html

11. H.G. Weldearegay, Journal of Tourism \& Hospitality, 6,6:1-8(2017). https://pdfs.semanticscholar.org/a85e/490b003f934d6fbded24dc4cfaaaf8877742.pdf 
12. C-Y. Chen, T-S. Wu, M-L. Li, C-T. Wang, International Journal of Computer Science \& Information Technology, 10,3:19-38(2018).

http://aircconline.com/ijcsit/V10N3/10318ijcsit02.pdf

13. A. Kobryn, Multi Criteria Decision Making, 12:153-167(2017). http://yadda.icm.edu.pl/yadda/element/bwmeta1.element.cejsh-e47f6b87-25af-40c0a7cb-50fd9f18d76d

14. N.S. Pendit, Ilmu Pariwisata, [Tourism Science], Jakarta: Pradnya Paramita (2004). [in Bahasa Indonesia]. http://library.um.ac.id/free-

contents/index.php/buku/detail/ilmu-pariwisata-sebuah-pengantar-perdana-olehnyoman-s-pendit-21300.html

15. A.M. Sammeng, Cakrawala Pariwisata, [Tourism Horizon], Jakarta: Balai Pustaka [in Bahasa Indonesia]. (2001).. http://inlislite.dispusip.jakarta.go.id/jaktim/opac/detailopac?id=3629

16. O.A. Yoeti, Tours and Travel Marketing. Jakarta: Pradnya Paramita (2003). [in Bahasa Indonesia]. http://library.um.ac.id/free-contents/index.php/buku/detail/toursand-travel-management-oleh-oka-a-yoeti-21102.html

17. J. Jusoh, T. Masron, N.F.A. Hamid, N. Shahrin, Academic Journal of Interdisciplinary Studies MCSER Publishing, 2,8:733-739(2013).

http://www.mcser.org/journal/index.php/ajis/article/view/800

18. Ikasari, H. I. Farida, Prosiding Seminar Nasional Multi Disiplin Ilmu dan Call for Papers, 2017:568-575(2017). [in Bahasa Indonesia].

https://www.unisbank.ac.id/ojs/index.php/sendi_u/article/view/5085/1590

19. Manimekalai, D. V. Karthik, International Journal of Current Research and Modern Education, 2,1:71-78(2017). http://ijcrme.rdmodernresearch.com/wpcontent/uploads/2017/02/155.pdf

20. O. Susetyarini, J.M. Masjhoer, Kepariwisataan, 12,1:41-54(2018). [in Bahasa Indonesia]. http://ejournal.stipram.ac.id/index.php/kepariwisataan/article/view/38

21. R. Lupiyoadi, Manajemen Pemasaran Jasa, [Marketing Management Services], Jakarta: Salemba Empat (2013). [in Bahasa Indonesia]. https://www.bukukita.com/Ekonomi-dan-Manajemen/Pemasaran/112380-ManajemenPemasaran-Jasa.html

22. P.T. Kotler, K.L. Keller, Marketing Management, UK: Pearson (2016). https://www.pearson.com/store/p/marketing-management/P100002737927

23. P.T. Kotler, J.T. Bowen, J. Makens, Marketing for Hospitality and Tourism, UK: Pearson (2014). https://digitalscholarship.unlv.edu/hotel_fac articles/120/

24. S.C. Bagri, D. Kala, Advances in Hospitality and Tourism: An International Journal of Akdeniz University Tourism Faculty, 3,2:89-115(2015). https://dergipark.org.tr/ahtr/issue/32311/359067

25. G.S. San, Jurnal Teknik Industri, 21,1:33-42(2019). [in Bahasa Indonesia]. http://jurnalindustri.petra.ac.id/index.php/ind/article/view/21773 